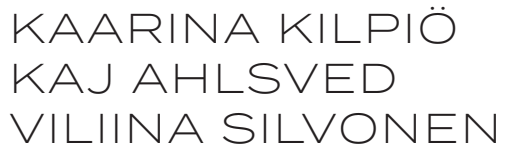

\title{
Oodi vertaisarvioinnille akateemisen keskustelun muotona
}

Etnomusikologian vuosikirja (myöh. EVK) on yksi niistä suomalaisista akateemisen tutkimuksen julkaisuista, jotka käyttävät vertaisarviointia.Virallisesti se otettiin käyttöön vuosikirjassa vuonna 1996, eli neljännesvuosisata sitten. 25-vuotisen taipaleen kunniaksi pohdimme tässä pääkirjoituksessa vertaisarviointia. Mitä se on, miksi sitä arvostetaan tiedeyhteisön itsesäätelynä ja millainen sen rooli on suomalaisessa etnomusikologisessa pääjulkaisussa? Pohdimme alan julkaisemiseen liittyviä olosuhteita, jotka ovat ikuisessa muutoksen tilassa. Pidemmän perspektiivin saamiseksi olemme pyytäneet kommentteja myös vuosikirjan meitä edeltäneiltä toimittajilta. Tekstin sitaatit ovat peräisin näistä kommenteista.

Arviointikäytäntö on olennainen osa tiedeyhteisön toimintaa: se on tieteelle elintärkeä asetelma, joka luo yhteisöllisyyttä. Vertaisarvioijat auttavat julkaisutahoa päättämään, mitä ja missä muodossa kannattaa julkaista. Arvioijien lausunnot ovat puheenvuoroja tieteellisessä keskustelussa, vaikka ne jäävätkin kirjoittajien, julkaisijoiden ja lausujien väliseen, julkaisuprosessia varten rakennettuun tilaan.

Vertaisarviointityö on aikaa vievää, ja se tehdään omien töiden ohessa useimmiten ilman erillistä rahallista korvausta (poikkeuksiakin on). Arviointi katsotaan kuuluvaksi tutkijan työnkuvaan, kuten jokunen muukin luottamustehtävä itse tutkimuksen ohella, esimerkiksi vaikuttaminen oman alan tieteellisessä seurassa. Rahallisen korvauksen sijasta nimettömänä arvioiva tutkija voi puolestaan luottaa omien tuotostensa tulevan yhtä lailla anonyymisti kommentoiduiksi. Tässä näyttäytyy tutkimusyhteisön keskinäisen tuen olennainen merkitys alaa ja tieteellistä keskustelua kannattelevana voimana.

Toisinaan vertaisarviointikäytäntö voi tuottaa henkisiä mustelmia ja eri asteisia pettymyksiä, jos arvioitavan ja arvioijien lähestymistavat ovat toisistaan liian etäällä. Internet on väärällään alan sisäistä huumoria vertaisarvioinnin sudenkuopista, kuten 
muustakin akateemisesta toiminnasta. Maailmanlaajuisesti leviävät sosiaalisen median parodia- ja vertaistukisisällöt kertovat osaltaan tutkijan ammatin ja siihen liittyvien prosessien henkilökohtaisesta ulottuvuudesta. Ne luovat omalta osaltaan myös yhteisöllisyyttä: tiukkaakin palautetta saadessa säilyy tietoisuus siitä, että kyse on laajemmasta akateemisesta käytännöstä.

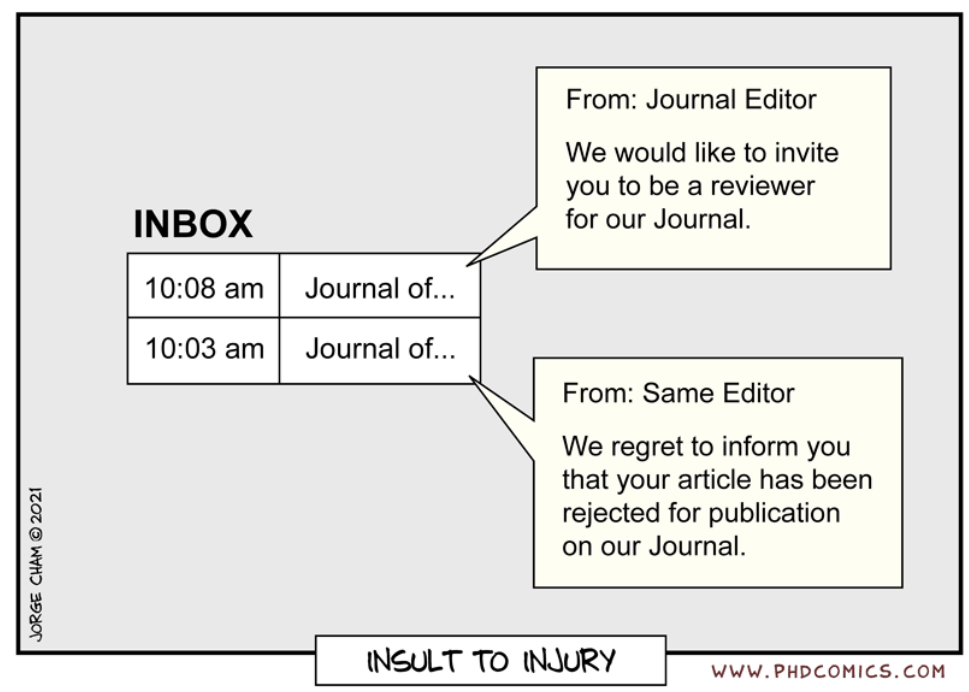

Kuva 1. "Piled Higher and Deeper" by Jorge Cham, 2021. Lähde: www.phdcomics.com

Jos uhkaa syntyä railo kirjoittajien ja arvioijien - tai samaa artikkelia arvioivien näkemysten välille, ovat journaalin toimittajat avainasemassa sen silloittamisessa ja keskustelun jatkumisessa. Yhtäältä toimittajat menevät takuuseen arvioijien pätevyydestä lausua käsikirjoitusta koskevia käyttökelpoisia korjausehdotuksia ja julkaisusuosituksen. Toisaalta toimittajien rooliin kuuluu auttaa kirjoittajia saamaan selkoa muutosehdotusten otollisimmasta toteuttamistavasta ja antaa yksityiskohtaistakin palautetta.

Vertaisarviointiprosessi muokkaa julkaisun linjaa. Vaikka linja muotoutuu ensisijaisesti tarjottujen artikkelien myötä, ovat myös vertaisarvioijien korjausehdotukset ja julkaisusuositukset keskeisiä etenkin teoreettisen ja metodologisen keskustelun mutta myös kysymyksenasettelun kannalta. Se, mitä julkaisun sivuilla on lopulta luettavissa, on siis kirjoittajan, arvioijien ja toimittajien yhteisen keskustelun hedelmä. 


\begin{tabular}{|l|}
\hline AA \\
\hline$\quad$ Reviewer 2 Must Be Stopped! \\
Iyt Reviewer 2 Must Be Stopped! \\
Public group \\
This group is for those who believe Reviewer 2 must \\
be stopped (see definition below). \\
In the name of science and all that's good and fair in \\
life. Stop this madness! \\
On this Facebook group, we probably won't get our \\
act together to take any concrete steps for stopping \\
Reviewer 2 (e.g., by challenging/changing the peer
\end{tabular}

Kuva 2. "Vertaisarvioija 2:n pysäyttämiseksi" perustetun satiirisen Facebook-ryhmän Tietoja-sisältöesittely. Lähde: kuvakaappaus ryhmästä, https://www.facebook.com/ groups/71041660468.

Vertaisarvioinnin kaksoissokkoperiaate poistaa prosessista ennakkoluulojen, identiteettikysymysten ja henkilökemioiden tyyppiset häiriöt - ideaalitilanteessa. On esitetty myös epäilyjä siitä, että anonymiteetti "luo tyhjiön, joka auliisti täyttyy ennakkoasenteilla" (Michael ym. 2021). Arvioijat luovat aina lukiessaan jonkinlaista käsitystä myös tekstin taustalla olevasta ajattelusta ja metodologiasta sekä kirjoittajasta/kirjoittajista. Arvioinnin kohteena olleiden tekstien kirjoittajat rakentavat hekin arviointilausuntojen perusteella väistämättä oman käsityksensä siitä, millaisin oletuksin ja kompetenssein arvioijat ovat olleet liikkeellä. Tiedeyhteisön eettisten periaatteiden mukaisesti kaikkien osapuolien tulee silti pitää tärkeimpänä itse tutkimusta ja sen tulosten välittymistä lukijalle.

Edeltävä vuosikirjaa ja tieteenalan julkaisemista reflektoinut kirjoitus (Kytö \& Rantanen 2014) totesi vertaisarvioinnin osoittaneen selvästi toimivuutensa alkuajan kitkasta huolimatta. Anonymiteetin voitiin todeta säilyneen tarvittavassa määrin, ja kirjoittajakunta oli pian sopeutunut tasa-arvoiseen roolitukseen arvioitavina ja arvioijina. Artikkelien taso nousi asiantuntevien vertaisehdotusten johdosta. Jo alkuvaiheessa oli selvää, että toimittajien työ ei siirtynyt arvioijien harteille: toimituksen kanta ei useinkaan ollut identtinen arvioijalausuntojen kanssa vaan muotoiltiin jokaisen artikkelin kohdalla huolellisesti erikseen.

Monet kyselyymme vastanneista vuosikirjatoimittajista nostivat esiin, että pienessä tiedeyhteisössä on toisinaan vaikeaa säilyttää anonymiteetti arvioijan suuntaan. Eräs heistä huomautti, että arvioijat todennäköisesti merkittävältä osin tietävät tai 
arvaavat kirjoittajien henkilöllisyyksiä esimerkiksi seminaarien tai symposiumien esitelmien pohjalta. Anonymiteetti on siitä huolimatta kunnia-asia, jota pidetään ammattimaisesti kiinni:
Anonymiteetti toimii teoriassa hyvin. Oman kokemukseni mukaan anonymiteetistä pidetään ammattimaisesti kiinni. Kukaan ei avoimesti puhu turuilla ja toreilla tekemistään vertaisarvioista ja/tai niiden otsikoista edes jälkikäteen julkaisun jo ilmestyttyä. Virallisesti siis arviointiprosessi on anonyymi.

\begin{abstract}
Akateemisissa töissä "henkilön sivuuttaminen" tuotoksia arvioitaessa kuuluu olennaisena osana peruskoulutukseen, ja samoin on esteellisyyden tunnistamisen laita. Saamamme palaute ja toimituskunnassa kertynyt kokemus viittavat siihen, että oman esteellisyyden havaitsevat arvioijat ovat osanneet tarvittaessa kieltäytyä arvioijatehtävästä. Toimittajakunta osaa pienessä tutkimusyhteisössä usein jo etukäteen havaita esteellisyyksiä ja olla turhaan pyytämättä tiettyä arvioijaa. Kun "kaikki tuntevat kaikki”, voi arvioijaksi kysyttävä jossain määrin luottaa toimittajien apuun jääviyden arvioimisessa ja harkita tehtävän vastaanottamista tämän luottamuksen pohjalta - toki päävastuu on arvioijalla, joka tuntee tilanteensa yksityiskohdat.
\end{abstract}

Jääviyttä tuottava toiminta - kuten ohjaaminen tai tarkastajana toimiminen - onkin ajanpuutteen ohella usein kokeenempien tutkijoiden syy kieltäytyä tarjotusta vertaisarviointitehtävästä. Vastaavasti nuoremmilla, hiljan väitelleillä tutkijoilla saattaa olla jonkinlainen kynnys ottaa vastaan ensimmäisiä arviointitehtäviään. Tutkijanuran alkuvaiheissa voi olla hankalaa arvioida, millainen perehtyneisyyden aste kulloisenkin artikkelin aiheeseen on riittävä. Myös tavalla tai toisella tapahtuva paljastuminen toisen - varsinkin vanhemman - tutkijan kritisoijaksi saattaa arveluttaa:

Anonyymiteetin tulisi kulkea kahteen suuntaan. Toisinaan tapahtuu sellaista, että arvioija kieltäytyy arvioimasta tekstiä, koska arvelee itse paljastuvansa ja joutuvansa vaikeuksiin. Tämä mielestäni kertoo siitä, että alalla vallitsee epäterveellisiä pelkoja. Ehkä tutkijakoulutuksessa pitäisi kiinnittää enemmän huomiota kritiikinsietokykyyn.

Kommentin "epäterveellisissä peloissa" voi olla taustana se, että arvioijapesti on luonteeltaan luottamustehtävä: arvioija antaa jotain takaisin tutkimusalalle ja samalla näyttää anonymiteetin suojassa omat tutkijantaitonsa. Aloittelevaan arvioijaan saattaa iskeä pienimuotoinen huijarisyndrooma: hän saattaa murehtia, johtaako lausunnon kirjoittaminen omien heikkouksien päätymiseen pyöriteltäviksi alan keskustelussa. Esimerkiksi perehtyneisyyden pinnallisuus - kuviteltu tai todellinen suhteessa johonkin artikkelin aspektiin voi huolestuttaa ja johtaa kieltäytymiseen 
tehtävästä. Toimittajien on tällaisissa tilanteissa hyvä toimia tukena ja avoimena keskustelutahona: vertaisarvioijan tehtävät ovat osa tutkijayhteisöön kotiutumista, joka ei ole soolosuoritus.

Kommentoijan mainitsemat kritiikin vastaanottamisen taidot ovat nekin osaamisen alue, jota ehkä kannattaa pohtia tutkimusyhteisössä nykyistä enemmän. Kriitikinsieto on keskeistä ammattiosaamista sekä nuorten että kokeneiden tutkijoiden kohdalla. Refereekäytännön ollessa uusi EVK:ssa silloinen toimittaja Pirkko Moisala pani merkille, että monet kokeneet tutkijat odottivat kirjoitustensa kelpaavan julkaistavaksi sellaisinaan (Kytö \& Rantanen 2014: 12). Kun käytäntö on alalla nyttemmin vakiintunut, tietävät niin nuoret kuin pitemmälle edenneetkin tutkijat saavansa kritiikkiä matkan varrella ja osaavat oletusarvoisesti suhtautua siihen. Onkin tärkeää tunnistaa, mitä ja miksi kritisoidaan: arviointi ei kohdistu henkilöön, eikä arviointi perustu arvioijan mielipiteisiin tai mieltymyksiin, vaikka ne toisinaan voivatkin näkyä arvioissa.

Pienellä alalla, jolla humanistit kamppailevat niukoista resursseista, voivat synkimmillä hetkillä hautua ajatukset arvioijasta ilkeänä haamukirjoittajana. Ilkeily - esimerkiksi turhien "heittojen" muodossa - ei silti noussut esiin ongelmana pienimuotoisessa kyselyssämme. Toivoaksemme alalle on rantautunut ajattelutapa, jossa vertaisarviointikäytäntö mielletään nimenomaan keskusteluksi. Tätä tukevat myös useat entisten toimittajien kommentit, joissa toivotaan, että "luvanmyöntämismentaliteetin" sijaan arviointi koostuu kriittisestä mutta rakentavasta vuoropuhelusta.

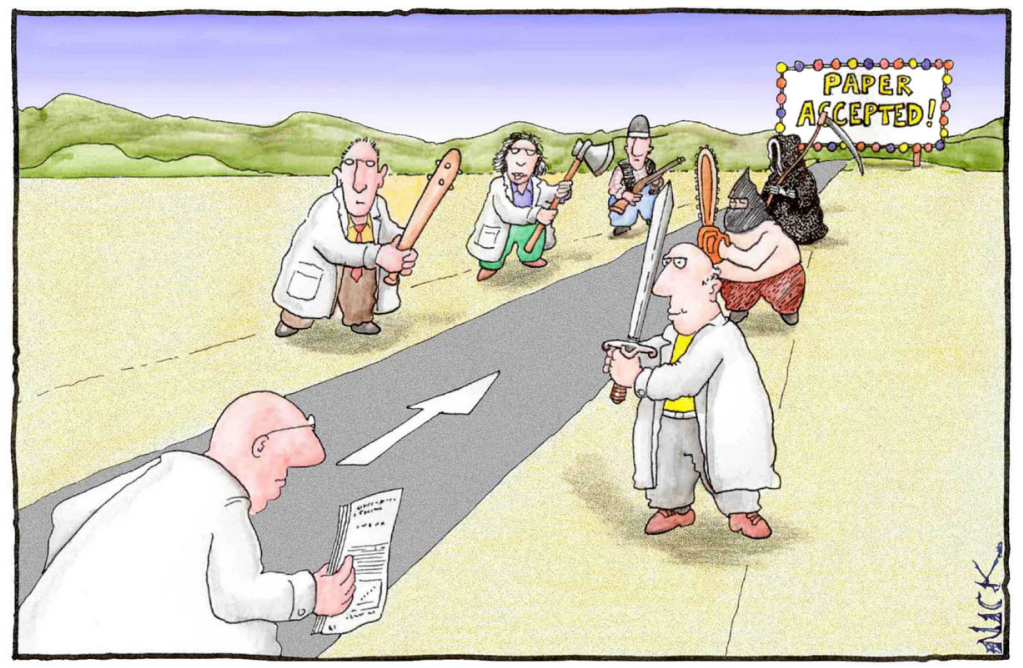

Most scientists regarded the new streamlined peer-review process as "quite an improvement."

Kuva 3. Piirros: Nick Kim / Science and Ink. Lähde: https://scienceandink.com/. 
Vuonna 2016 Etnomusikologian vuosikirja otti käyttöön Open Journal System -julkaisualustan (myöh. OJS), minkä myötä viestiminen kirjoittajien ja arvioijien kanssa on muuttunut. Alustaan siirtyminen tuntui toimitustyötä alkuvuosina tehneen mukaan ensin oudolta, "koska piti epävirallisten viestien lisäksi lähettää alustan kautta virallisia pyyntöjä”. Nämäkin käytännöt ovat nyt muotoutuneet totutuksi tavaksi, ainakin toimittajille. OJS on hyvä työväline siinä mielessä, että se helpottaa kommunikointia, kun prosessissa on mukana monta liikkuvaa osaa. Alustaan tallentuu lausuntojen lisäksi pysyvästi myös keskusteluketjuja ja toimituspäätöksiä. Alustalle tallentuvat keskustelut lisäävät koko prosessin oikeudenmukaisuutta ja helpottavat hyvän tieteellisen käytännön periaatteiden toteutumista. Kuten eräs meitä edeltävä toimittaja toteaa:

Vertaisarviointitunnusta annettaessa TSV:n ohjeissa oli, että toimitusprosessista pitää säilyttää/arkistoida tiedot, jotta hyvä tieteellinen käytäntö voidaan todentaa tarvittaessa (jos tuli ongelmia tms). Tämä oli helppoa, kun viestintä painottui OJSään.

Hyvän tieteellisen käytännön toteutumisen varmistamisen ja jatkuvan saatavuuden lisäksi sähköisellä alustalla viestiminen keventää sähköpostilaatikon kuormitusta - vaikka OJS ilmoittaa uudesta viestistä sähköpostiin, löytyy kaikki viestittely itse alustalta helpommin kuin sähköpostilaatikkoa perkaamalla. Toki ainakin nykyinen toimituskunta on käyttänyt omaa harkintaa viestittelyssä, ja esimerkiksi arvioijia on ensin lähestytty omasta sähköpostiosoitteesta. Kontakti omien verkostojen ulkopuoliseen, mahdollisesti julkaisua ennalta tuntemattomaan tutkijaan saattaa olla helpompi saada, kun viesti ei tule tuntemattoman alustan kautta, vaan yksittäisen henkilön sähköpostiosoitteesta.

Kuten ylempänä siteeraamamme vuosikirjan 2014 pääkirjoitus mainitsee (Kytö \& Rantanen 2014, 15), vertaisarvioijien saaminen on tuottanut vuosikirjan toimittamiseen jatkuvia haasteita. Joskus myös tavoitettavuus on tutkimusyhteisössä heikkoa kesäaikaan painottuvan toimitusprosessin aikana. Ensin mainittua pulmaa ajatellen olemme kehitelleet muutamaa uutta käytäntöä EVK:n vertaisarviointiin. Ryhdymme parantamaan arvioijien saatavuutta ja heidän asiantuntemusalueitaan koskevaa tietämystämme rakentamalla toimituksen käyttöön arvioijapankin, jollaista on julkaisulle suunniteltu jo jonkin aikaa. Lisäksi otamme käyttöön raportoivan palautteen arvioijalle: kerromme, miten prosessi eteni arvioinnin jälkeen joko julkaisuun tai hylkäykseen, ja laadimme haluttaessa todistuksen arvioijana toimimisesta.

Avaamatta yksittäisiä prosesseja liikaa voimme todeta, että tänäkin vuonna arviointiprosessi on toiminut: nyt julkaistavat artikkelit kaikki paranivat prosessissa, ja osa käsikirjoituksista jäi kirjoittajiensa pöytälaatikoihin odottamaan tulevia julkaisuja. 
Vuosikirjassa julkaistaan nyt kuusi vertaisarvioitua artikkelia, jotka osoittavat hienolla tavalla tieteenalan aiheiden ja näkökulmien monipuolisuutta sekä tarjoavat laadukasta luettavaa. Vaikka vuosikirjalla ei ole teemaa, rakentuu julkaistavista artikkeleista mielekäs kokonaisuus. Artikkelien välillä on temaattisia ja näkökulmallisia yhteyksiä, kuten alla olevista tiivistetyistä luonnehdinnoista voi päätellä, mutta myös toisiaan täydentäviä teoreettisia viitekehyksiä.

Antti Okko tarkastelee artikkelissaan venäläisen rock-musiikin lehdistövastaanottoa Yhdysvalloissa perestroika-ajan kontekstissa. Hänen tapaustutkimuksensa rakentuu niin sanotulle kehysanalyysille hard rock -yhtye Gorky Parkin Amerikan-valloituksen uutisoinnista sekä niistä laajemmista narratiiveista, jotka hahmottuvat rakennettujen kehysten taustalta. Juho Hänninen on syventynyt viiden Helsingin Lepakkoluolan skenessä toimineen henkilön omaehtoisiin uriin, jotka ovat rakentuneet kiinnostuksesta alakulttuuriin ja toimijuudesta nuorisokulttuurin kentällä. Elämäkertahaastatteluihin ja elämänkulkuanalyysiin perustuva analyysi valottaa prekaarien urapolkujen lisäksi yhteiskunnallisen ilmapiirin muutoksia. Inka Rantakallio pureutuu kahteen suomiräpin naistoimijoiden verkostoon ja tarkastelee sisällönanalyysin, diskurssianalyysin ja vastatilan käsitteen avulla näiden syntyä ja toimintaa sekä vaikutuksia miesvaltaisella rap-kentällä. Artikkeli paljastaa muun muassa median asenteiden mielikuvia luovan voiman. Nina C. Öhmanin artikkeli paneutuu etnomusikologisen pedagogiikan potentiaaliin polarisoituvassa keskusteluympäristössä. Hän tarkastelee etnomusikologian opetusta kahden eri mantereilla toteutuneen pedagogisen kokonaisuuden pohjalta ja pohtii demokraattisen kommunikoinnin fasilitoimista. Klisala Harrison tutkii artikkelissaan saamelaisten teatterituotantojen musiikissa ilmenevää alkuperäistä kosmopoliittisuutta Norjassa toteutetun kenttätyön pohjalta. Hän toteaa, että tuotannot esittävät dynaamista ja liukuvaa saamelaisuutta, joka sisältää ääni- ja liikeilmaisua kaikkialta maailmasta, mutta on samalla juurtunut siihen, mitä saamelaisena oleminen merkitsee tänään ja historiallisesti. Vesa Kurkelan soitinhistoriallisen artikkelin keskipisteenä on mandoliini sekä erilaiset kokoonpanot, joiden osana instrumentti on historiansa kuluessa ollut. Mandoliinin ja mandoliiniorkestereiden kotoutuminen Euroopan laajuisesti - ja yksityiskohtaisemmin Suomessa - valottaa soittimen ympärille virinneitä kulttuurisia, yhteiskunnallisia ja taiteellisia konteksteja.

Haluamme kiittää lämpimästi kaikkia tämänvuotisen Etnomusikologian vuosikirjan kirjoittajia ja arvioijia. Olette mukana edistämässä tutkimuksellista keskustelua, yhtä tieteenalan ydinprosesseista. Näin on myös niiden arvioijien kohdalla, joiden lukemia ja kommentoimia tekstejä ei julkaista tämänvuotisessa vuosikirjassa. Toimitus rohkenee toivoa, että vuosikirja on vankassa nousukiidossa vuoden 2020 numeroon tarjotun vähäisen artikkelimäärän jälkeen. Avain tekstien määrän lisäämiseen 
ja laadun varmistamiseen onkin koko etnomusikologisen tiedeyhteisön käsissä, tutkimusta käsittelevän keskustelun ja kotimaisten julkaisujen arvostamisessa kokonaisuutena. Tämä toteutuu opetustilanteissa, kahvipöydissä, konferenssi-illallisilla - kohtaamisissa, joissa arviointiprosessi elää jatkuvana käytäntönä.

\section{Kirjallisuus}

Kytö, Meri \& Rantanen, Saijaleena (2014) "Etnomusikologian vuosikirjan merkitys musiikintutkimuksen alalle Suomessa". Etnomusikologian vuosikirja 2014, vol. 26, 8-25. https://etnomusikologia.journal.fi/article/view/66784 (luettu 8.11.2021)

Michael, Ann \& Rapple, Charlie \& Vines, Tim \& Irfanullah, Haseeb \& Meadows, Alice \& Wallace, Jasmine \& Harington, Robert \& Luther, Judy (2021) "Ask The Chefs: How Does Identity Influence Peer Review?". Scholarly Kitchen https://scholarlykitchen.sspnet.org/2021/09/16/ask-the-chefs-peer-reviewidentity/ (luettu 16.11.2021) 